\title{
FACTORS THAT INHIBIT OR PROMOTE THE INTEGRATION OF ICT IN EDUCATION
}

\author{
Paula Quadros-Flores ${ }^{1}$, António Flores ${ }^{2}$, Altina Ramos ${ }^{3}$ \\ ${ }^{1}$ Polytechnic Institute of Porto, High School of Education (PORTUGAL) \\ ${ }^{2}$ Polytechnic Institute of Porto, Higher Institute of Engineering of Porto (PORTUGAL) \\ ${ }^{3}$ University of Minho (PORTUGAL)
}

\begin{abstract}
The integration of digital technologies in education stimulates methodological changes with an impact on the ways of teaching to learn and learning to learn and, therefore, requires up-to-date digital resources available for innovative educational practices. In general, there have been projects that equipped Portuguese schools, but without concern for teacher training and, therefore, it is crucial to understand if the inclusion of these resources in the current educational environment promotes innovative practices or if there are still obstacles preventing change and the development of a student profile for the 21st Century [1]. The purpose of this study is to understand if the current reality still hinders change in education, or facilitates this change by making available a digital technological educational environment that supports innovative and dynamic practices that prepare students for the reality in which they live in. We also want to know if a classroom equipped for the frequent and effective use of ICT is enough and what makes teachers include digital technological resources in their educational practices.
\end{abstract}

In this context, an exploratory quantitative and qualitative study was chosen. Data collection was carried out by open and closed questionnaire surveys. As for the analysis, in the first phase, three open questions were analyzed in 14 questionnaires applied to trainees in public elementary schools (1st cycle of basic education), and two open questions in five questionnaires applied to cooperating teachers, guiding these students to teach in the same schools. In the second phase, three closed questions were analyzed in a questionnaire applied to approximately 1200 teachers in the Porto metropolitan area.

Trough the analysis of the results obtained in both phases mentioned above, four categories related to the obstacles that currently exist in primary schools and that negatively influence the teaching and learning process were identified. It was not surprising that the existence of digital technological resources in the educational context is not sufficient, since there are other factors that inhibit or promote the use of ICT. The obstacles which inhibit the frequency of use impose measures within the context of teacher training, including a reflection on the course syllabus. The factors that promote the use of ICT focus mainly on three categories. It was possible to verify that the success of the integration depends on: a) the articulation of aligned projects that involve the availability of various technological resources, namely computers and wireless networks; b) the context of the educational community; c) the training of children, the technical and pedagogical training of teachers and their creative capacity in the construction of strategies and didactic resources as well as their vision of education.

Keywords: Innovation, Initial teacher education, ICT, Methodological renewal, Opportunities and Obstacle.

\section{INTRODUCTION}

The inclusion of ICT in education has been a growing concern in Portugal, since it requires political, social, economic and educational commitments in the change of educational scenarios. It challenges large projects to make the school environment truly digital, as it requires not only technological equipment for students, but also teacher training. In fact, teachers require a solid technical and technological preparation to integrate digital media into educational activities which will promote the development of students' abilities, skills and attitudes in order to respond to the students' profile for the 21st century, as defined by Oliveira-Martins [1]. It should be noted that the inclusion of digital technologies emphasizes the process of teaching and learning in the centre of which the student is the subject responsible for developing their own knowledge. The dynamics of this process integrates a) the classroom where the educational activities take place; b) the teacher, creator and manager of 
learning contexts that favour the development of skills that stimulate the development of cognitive and social skills in the students; The educational dynamics of the process includes (1) the classroom that allows the educational activity, (2) the teacher who favours the development of competences providing students with the opportunity to grow academically, both in skills and autonomy, (3) the student who decides his path and objectives, applying efforts according to his learning pace, his needs and interests, his relationships and connections. This dynamic educational gear combines the classroom which "enables", the teacher who "provides" and the student who "responds" to each other (Figure 1). It makes sense to a paradigm which requires technological equipment with wireless network, a teacher with creative strategies and entrepreneur in problem-solving and interest-developing problems, with ICT scientific, pedagogical and technical knowledge, visionary in the selected methodologies to provide all students with opportunities to grow in different learning spaces and paces, according to each one's understanding; a responsible student who knows how to take advantage of educational opportunities by responding with assertive decisions that allow for his integral development.

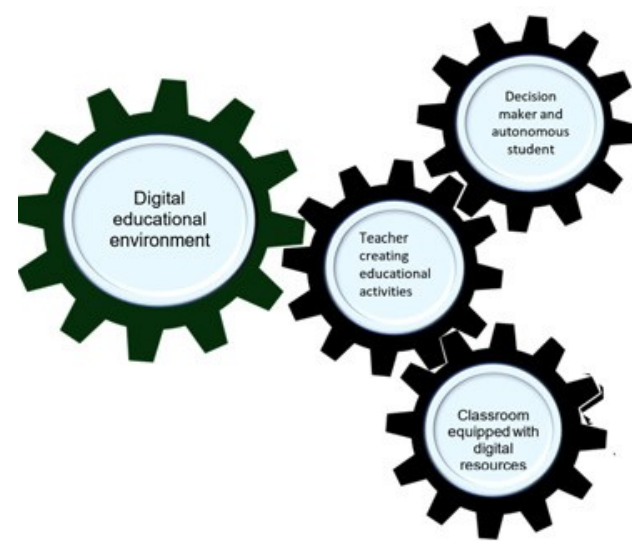

Figure 1. Digital Environment Engagement.

In Portugal, there have been several projects, including Minerva (1985/1994 - Electronic Means in Education, Rationalization, Valorisation, Updating), whose purpose was to contribute to the viability of a national computer industry, as in other countries such as the United Kingdom, France, the Netherlands and Sweden, but assuming a decentralized model that relied on autonomy and initiative promoting diversity [2]. The goal of the Nónio Sec. XXI Program was 1 interactive board for every 3 classrooms, but it failed to guarantee that the teachers themselves felt competent enough to integrate these boards into a pedagogical, safe and comfortable logic [3]. Later, EDUTIC and CRIE followed, as well the Technological Plan for Education, composed of three areas of activity (Technology, Content and Training) from which the projects e.escola, e.professor and e.oportundiades were created. Here, we highlight the project Escolas, Professores e Computadores Portáteis that evaluated the impact on the school plan, teachers and students. In search for better results and in order to facilitate the integration of ICT, two innovative projects have been developed in the context of teacher training and carried out in the $1^{\text {st }}$ Cycle of Basic Education (Primary School): Internet@EB1 and CBTIC@EB1. The purpose of the Internet@EB1 Program was to monitor the educational use of the Internet in public schools, and so it was necessary to carry out pedagogic supervision actions (three to four visits) in the schools themselves, by teachers or monitors affiliated to Higher Education Institutions (Universities and Higher Education Schools). Not only did it enable teachers to produce school web pages, but also perform work sections with students to develop basic ICT skills. According to the evaluation report 2004/2005 [4], in the Porto region, 765 web pages were produced in schools of the 1st Cycle, but no communities of practice were created, nor research activities carried out under this project. Some coordinators have shown that the impact on ICT integration has not been high, others believe that it has had a good impact thanks to the motivation of the teachers and the enthusiasm and commitment of the students, but they draw attention to the need for a unified national policy for the integration of ICT in the schools of the 1st Cycle of Basic Education. The CBTIC@EB1 project, Basic Skills in ICT in EB1, promoted by the Ministry of Education, through the CRIE Mission Team, continued the project and marks a new chapter ICT Integration training. Higher Education institutions were also involved to promote the use of computers, networks and Internet in public schools of the 1st Cycle of Basic Education. In general, this type of training was similar to the previous project, but managed differently. It aimed to train both teachers and students for the use of ICT as an educational resource in the service of curricular disciplinary and transversal learning, including those that refer to the research and 
critical use of information. According to the 2005/2006 report [5], the Project registered a reduced number of visits to the schools by the monitors, and the class teacher is not really responsible for the work to be done with the ICT, in fact, several district coordinators recognize that school portfolios and web pages were essentially the product of the monitors' work, although teachers showed positive attitudes towards ICT integration with students and greater technological mastery. However, in the Braga district, the animators who attended training and were interacting online with the CBTIC coordinator and the various trainers allowed a systematic support to the animators' work [6]. In addition, they say that the interaction between the different teams has helped to overcome less positive situations. Although they mention some resistance from some professors, they also highlight a very positive work which involved Web research related to subjects of the various curricular areas, production and sharing of texts related to the subjects addressed in the Web class, creation of Web pages and collaborative projects.

As for teacher training, it was carried out according to the training plans elaborated by grouped and non-grouped schools, taking into account the diagnosis of the training needs of the respective teachers, but also the frequency of continuous training initiatives by the teacher as long as it contributes to their professional development. At the level of ICT competence enhancement, there is a modular, sequential and disciplinarily oriented Program with the aim of generalizing the training and certification of ICT skills in the educational community and promoting the use of ICT in teaching and learning processes and school management.

After hearing researchers connected to several universities, Costa [4] presents the study, ICT Competencies - Implementation Study Vol. 1, and in 2009 [7] Volume II is published, presenting the methodologies adopted and the results obtained. The ICT Competency Certification Program was regulated by Administrative Rule no. 731/2009, of July 7 [8], and the normative conditions for the implementation of the ICT skills training and certification program for teachers were established, a document that recognizes the importance of ICT integration in the teaching-learning processes and the new management of the school as a unique condition for school success and expression of the future of the school and recognizes the need to modernize current schools to consolidate the role of ICT as a basic tool to learn and teach in the new age [9]. In general, regarding the measures to be implemented, they show that there are needs: support for teachers, both in technology and curricular in the pedagogical sense; development of a culture of dialogue between the entities involved; training based on the needs of teachers and schools, in the classroom, syllabus and disciplinary methodologies; of actions involving teachers from the same school and disciplinary group; of more school initiatives; of giving priority to training workshops. According to the GEPE [10] the lack of qualifications is still seen as a strong barrier to the use of ICT.

Currently, public schools are generally benefiting from a set of investments that have enabled Portuguese schools to equip themselves with computer equipment, technological infrastructures and services that are appropriate to the school situation, in order to contribute to an improvement in the learning and teaching experience, as well as the quality and efficiency of school management [11]. Effectively, there are policies that ensure the safety of school spaces and equipment (as referred to in the aforementioned decree) and new projects that leverage the technological equipping of schools: Computers, Interactive Whiteboards and Projectors in the classroom, with internet connection, allowing the mobilization of digital educational resources, according to the GEPE [10], the low availability of equipment was a strong barrier to the use of technology in schools, so there was a need to increase its allocation. In addition, the reduced availability of equipment for free use of teachers and students was, at the time, one of the main barriers to use pointed out (idem). Hence the importance of the availability of computers, Internet access and printers outside the classroom period; Local Area Networks in Schools, since schools showed limited access speeds and were insufficient. It should be noted that the authors (idem) still refer the need for rooms, materials and the logistics associated with the assembly and disassembly of equipment to use ICT in class as an important barrier; the insufficiency of equipment for free use by teachers and students (the use of ICT is very confined to the classrooms and ICT rooms); The mismatch of the duration when computer resources are available for free use to the needs of teachers and students. According to the National Association of Computer Teachers [12], the existing equipment and services of the schools continue to lack daily maintenance and proximity, and the problems are solved at the moment to make the class possible. The author (idem) recalls that to avoid this situation the position of ICT coordinator was created, later replaced by the PTE Team. However, the positions of the coordinator of the PTE team were not always assigned, and when they were, they contemplated non-working component hours at the institution level and were considered insufficient, and the association proposed to create a Coordination structure for Technological Innovation. Is it worth highlighting the team of educational resources and technologies 
that propose ways and modalities for the integration of ICT in curricula, syllabus and training guidelines and components, promotes research and disseminates studies; proposes guidelines for a rational pedagogical and didactic use; develops, monitors and evaluates innovative initiatives and promotes educational success; generates, maintains, enhances and improves the educational repository of digital educational resources and contributes to the definition of terms of reference for the initial, continuous and specialized training of educators and teachers in the area of ICT use. In spite of the many efforts, "the majority of pedagogical and research projects, present and of the last thirty years, in the area of ICT education continues to denounce, in its own way, a narrow instrumental vision" [2]. The author adds the need for strategic frameworks and rigorous operational monitoring to foster incremental innovation projects in very conservative social systems, such as education, in the sense of cultural changes and pedagogical practices recreated to the world of rapid change.

\section{METHODOLOGY}

An exploratory quantitative and qualitative study was chosen. Data collection was carried out by open and closed questionnaire surveys. As for the analysis, in the first phase, three open questions were analyzed in 14 questionnaires applied to trainees in public elementary schools (1st cycle of basic education), and two open questions in five questionnaires applied to cooperating teachers, guiding these students to teach in the same schools. In the second phase, three closed questions were analyzed in a questionnaire applied to approximately 1200 teachers in the metropolitan area of Porto.

\section{RESULTS}

The results will be presented in three subchapters, taking into account the open answers of the interviewed (initial teachers) (3.1), the cooperating teachers, the supervisors of these students (3.2) and the three closed questions in a questionnaire applied to about 1200 teachers in the metropolitan area of Porto (3.3).

\subsection{Results of the questions concerning the use of ICT by teachers during initial training}

Three open questions were analysed in 14 questionnaires applied to students undergoing traineeship (initial teacher training) in public primary schools (1st Cycle of Basic Education). We wanted to know why they select digital resources when planning their classes, what is the added value of these resources in the teaching and learning process and what obstacles inhibit their use.

Regarding decision to integrate digital technological resources, the analysis of the answers allowed the creation of two categories that appear to be the main education stakeholders and that are an effective concern in the design of the class: students and teachers (Table 1).

Table 1. Factors that promote the selection of digital resources.

\begin{tabular}{|c|c|}
\hline Concerns about & Reasons for the selection of ICT resources \\
\hline Teacher & $\begin{array}{l}\text { - feel the pleasure of teaching; } \\
\text { - promote interaction; } \\
\text { - to use programs and simulators that favour the understanding and deepening of } \\
\text { themes; } \\
\text { - improve the teaching and learning process; } \\
\text { - diversify more interesting strategies and methodologies; } \\
\text { - help in class. }\end{array}$ \\
\hline Student & $\begin{array}{l}\text { - motivate, satisfy needs and interests; } \\
\text { - make the educational environment more familiar; } \\
\text { - make learning more meaningful; } \\
\text { - promote the construction of knowledge; } \\
\text { - engage, interact, excite; } \\
\text { - improve understanding, learn by visualizing, contextualizing; } \\
\text { - dynamize the class, improve the process of teaching learning to improve results }\end{array}$ \\
\hline
\end{tabular}


These results herald an added value of ICT as educational resources in education. According to the trainee teachers interviewed, in fact they constitute an added value because

"Promote school success and meaningful learning"; "Promotes the use of ICT in society and facilitates its use"; "facilitate learning in a meaningful and engaging way"; the students "explore and learn by exploring"; "prepares children for a conscious use"; "they learn from each other, with whom they are close and/or far away"; "is a more didactic, dynamic and exciting way"; "children feel integrated and motivated in learning"; "create a constructivist and dynamic learning environment"; "has a positive impact on my training, as it made me realize the positive impact on children"; "they are an asset to both teachers and students" because they motivate, promote positive interactions and a socioconstructivist climate; "they develop basic skills in the world"; facilitates the "connection between content and curricular areas ... which allows students to understand that the contents they learn are correlated"; "prepares students for permanent interactions in the world"; "promotes more dynamic classes through student involvement"; "students are moptivated and receptive to learn"; "they are motivating ... they bring the childrens' interests closer together"; "they allow freedom and autonomy"; "education becomes less expositive, involves students, ... allows sharing, brings to the classroom local elements and world knowledge that otherwise can not be accessed"; "they guarantee a contextualized and motivated learning"; "we are able to the students, approach the contents in a more attractive way and relate more robustly all the contents"; "allows experiencing, experimenting, motivating ..."; "overall motivating environment"; "openness to a "world" of information"; promotes the relationship between students and teachers"; "communication between students and sharing of ideas".

Regarding to inhibiting obstacles to the use of information and communication technologies (ICT), figure 2 shows the repeated frequency of such obstacles.

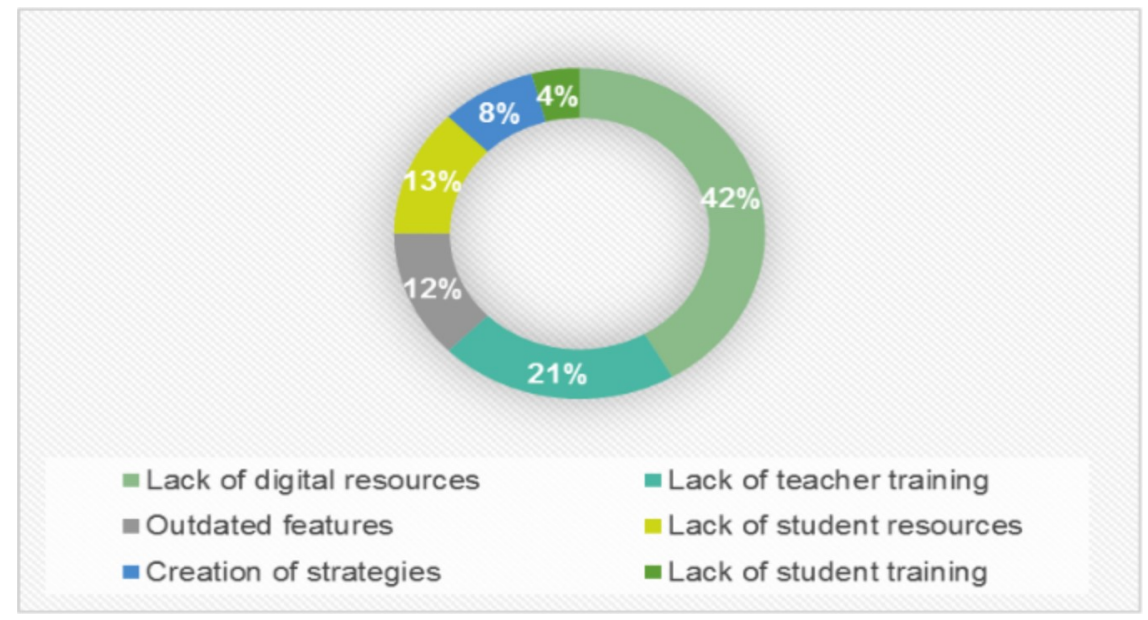

Figure. 2 Obstacles to the use of ICT.

Regarding the lack of resources, the trainee teachers interviewed report the lack of sufficient computers (taking into account the number of students and the programmed activity according to the purpose of the lesson), but also the lack of internet and wireless network, or the malfunctioning of the Internet, frequent Internet failures, the impossibility of using certain software or programs that require code that only the technician has. Regarding the lack of teacher training, it includes the training of the cooperating teacher and the trainee teacher. The latter warn that they have little knowledge about the use of ICT in the classroom, thus when planning the first impulse is to choose a traditional methodology, but they are aware that the inclusion of digital resources promotes a constructivist methodology by responding more to digital environments whose activities are focused on the learner and the learning process. They add that the lack of digital resources in the classroom requires changing rooms, causing "disorder in student behaviour" and encourages the repetition of resources which, in turn, "discourages students" because it causes routine and it does not captivate students' attention. On the other hand, "it requires creativity" and "research" on the part of the teacher to find new solutions that have a positive impact on the students. The lack of training of the student (child) and of technological equipment at home also conditions the strategies of the trainee teachers, namely in the use of platforms, methodologies such as the Flipped Classroom, visualization of videos for discussion. 


\subsection{Results of the teachers' opinions concerning the use of ICT by trainee teachers}

The analysis of the cooperating teachers' responses shows that they feel the added value of ICT inclusion in education in four dimensions: in methodological renewal, students, results, and in school. However, they also point out the obstacles and acknowledge that ICTs by themselves do not make a difference, but rather how they are used by teachers and students. Regarding the methodology, they reinforce that the integration of digital resources changes the way of teaching, makes the contents attractive and the possibility to research is an added value in the learning process and the use of different digital tools promotes creativity and autonomy. Regarding the student, they become more alert, awake, predisposed in learning and interacting with content because they feel motivated. In this sense, they find that students love to work with ICT, they are encouraged by what makes learning "more concrete", results are improved. As for the school, they believe that it "opens horizons of information and communication".

Thus "it is possible to change the traditional way in which the curricular contents are transmitted ... students are more predisposed for learning"; "It makes content more attractive to students"; "Research is an added value in the learning process"; "Various tools promote creativity and children love it"; "Added value when integrated in a pedagogical architecture designed to serve the students' development"; "Didactic and strategic enrichment improves the teaching and learning process"; "it allows students to improve their interaction with content"; "in school it expands horizons of information and communication"; "School curriculum leaves no time for further exploration and use of technologies"; "It is not technology that produces effects on students, but the way teachers use it"; "Teacher training is so important"; "Students are more motivated and attentive ... not permanently, so do not repeat the same resource ... diversification is beneficial and provides greater motivation"; "It awakes them ... makes learning more concrete"; "Makes content more attractive to students"; "Stimulates motivation".

\subsection{Results of the teachers' opinion teaching in the Porto metropolitan area regarding the availability of Resources and duration of use}

We wanted to know the availability of digital technological resources in relation to the personal and geographical characteristics and the time of use per week.

Results show that the youngest male teachers, aged between 29 and 47 years, are those with the highest qualifications and those who teach in urban or semi-urban areas are the ones that most refer to the availability of technological tools in the school. Results show also that those who use the computer use it more frequently at home than at school, with most teachers using more than four hours a week at home and only $22 \%$ more than ten hours, but the most use less than three hours in school and only $6 \%$ more than ten hours, thus confirming the relationship between the availability of resources and the use of the computer. However, the probability of using more weekly hours does not increase with the availability of technological resources, which indicates that there are other factors inhibiting the integration of ICT.

According to Costa [7] "... the introduction of technologies should be seen as a gradual process which teachers must undergo, in order to be able to make the changes that the technologies themselves suggest and can induce." In this context, the group, coordinated by the author, described five phases of development of the pedagogical use of technologies: Entry, Adoption, Adaptation, Appropriation and Invention. However, taking into account the time of use of the computer in the school per week and the technological resources available, we observed three distinct steps (Fig. 3), whose teachers' behavior may also vary, especially since there is a growing ICT training and in the type of technology used or available. 


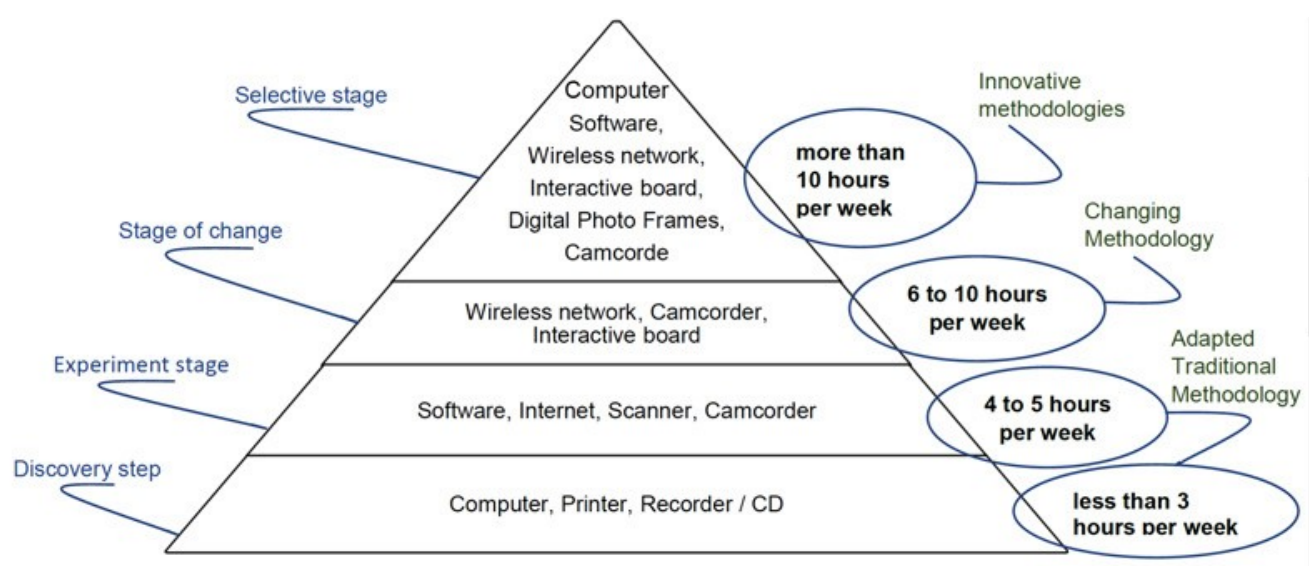

Figure. 3 Stages of change through the inclusion of ICT.

We named each stage; however, it should be noted that the steps are not fixed, but flexible because there are teachers who are in transition, perform mixed methodologies and may have different computer resources available. Thus, in the first stage of Discovery, it is important for teachers to use the computer at school, to have a basic set of tools: computer, printer, Internet and educational software. In this context, the probability of using computer resources increases with the availability of these in school, but the availability of these tools is not enough to use the computer frequently, perhaps the level of teacher training is also a key factor. It is understandable that at this stage teachers use a traditional methodology adapted to the technology, since they are in the learning phase of the tool and the concern doesn't appear to be focused on methodology, but rather on the capacity to use new tools. In the second stage, the stage of Experimentation, the majority of teachers, regardless of the availability or lack of resources, work less than three hours per week. Perhaps this is due to the level of teacher training in ICT which reveals lack of training and the type of computer tools available at school. The computer, the Educational Software, the printer, the Scanner, the CD player/recorder, and the Internet are tools that do not encourage the increased use of the computer at school due to its limitations. At this stage, it is natural for teachers to take on different attitudes: for some (those who find themselves in a more basic technological framework) it may represent the use of another work tool, reliving the same scenario with new accessories, maintaining the methodology and the profile of teacher and student so that technology has become an instrument of exposure and consolidation, adapting the traditional methodology to technology - Adapted Traditional Methodology; for others, it may represent a path to change, because they are able to use a renewed Methodology, that is, they are able to recreate scenarios, new learning environments, new ways of teaching and learning, new time spaces where the student is the knowledge builder. It changes the profile of student and teacher. Thus, they are prepared for Stage 3, Change, and are sufficiently capable of an Innovative Methodology. The availability of the interactive whiteboard, wireless network, camcorder and digital camera is more significant for teachers who use the computer during more hours per week in school, so it is possible to conclude that these are resources that stimulate the number hours of use of the computer in context. Teachers who work long hours with computers at school and who have technological resources available, are supposed to be able to develop new skills that will allow them to develop innovative methodologies.

\section{CONCLUSIONS}

The analysis of the results regarding the factors promoting the selection of digital technological resources leads us to conclude that there are two fundamental categories, the student and the teacher, influenced by two unique factors: process and results. These factors are reinforced in the results of the ICT analysis as an added value in the teaching and learning process that reveals the process as the mirror of the methodology and the results as the feedback of all the educational gear whose elements combine to respond to the transformations that occur in society driven by technological developments. Thus, in education, the driving force of this impulse is the teaching methodology which, according to our results, is a dynamic methodology, which promotes interaction with others and the world and the interests of the student, involving and integrating them into significant learning experiences that articulate knowledge and curricular areas in a constructivist and technological environment, contextualized and overcoming barriers of time and space. This 
environment is also conducive to a sense of freedom, openness and the development of multiple skills, including autonomy. It drives students by engaging them in the learning process where they explore, experiment, integrate, collaborate and build, making them also aware citizens in the correct use of digital technologies, preparing them for social life. It also drives the teacher who feels the positive effect on their students and seeks ICT resources, feels assuredly done professionally by seeing students' motivation and success. This drive motivated by methodological renewal requires not only technological resources in the classroom but also a capable teacher, which means technological mastery of digital tools, scientific domain of syllabus, creativity and entrepreneurship in the act of planning to give students the opportunity to grow in wisdom, skills and competence, attitudes and human and ethical values and relationships. Respondents reinforce factors inhibiting the inclusion of ICTs, lack of resources, training of trainees and students. The lack of resources promotes the methodological, strategic and resource routines, consequently the students' demotivation, imposes a change of room and this stimulates changes in the behaviour of students with negative repercussions in the learning process. The lack of training of teachers also limits methodological selection, creativity and entrepreneurship, and therefore highlights the need to revise the curriculum in initial training. The lack of training of the students conditions the strategies of teachers who use digital resources, also highlighting the need to observe ICT contents in the 1st CEB.

This scenario shows that, while improving the availability of classroom resources, in fact these are not in yet sufficient to promote change, in addition, it is necessary to keep in mind what kind of resources are available. According to the results of this study, there are resources that promote change: computers with wireless network connection, open to all types of software, interactive whiteboard, digital video camera, digital camera. In this context, it seems advantageous if the students have a mobile phone with internet access, since it can be integrated with multiple technologies. However, teacher training is also an inhibiting factor and, according to our results, it is a process that goes through stages and along the same teachers improve the capacity for methodological renewal. The change occurs when the availability of resources and teacher training meet the need for the frequent use of digital resources and methodologies that respond to current problems, needs and interests.

\section{REFERENCES}

[1] G. Oliveira-Martins (Coord.), "Perfil dos alunos à saída da escolaridade obrigatória”. Lisboa: República Portuguesa Ministério da Educação, 2017. Retrieved from http://www.dge.mec.pt/sites/default/files/Curriculo/Projeto_Autonomia_e_Flexibilidade/perfil_dos _alunos.pdf

[2] A. Figueiredo, "Histórias, Mitos e aspirações das TIC". Aprendizagem, TIC e Redes Digitais, pp. 13-27. Lisboa: CNE - Conselho Nacional de Educação, 2017.

[3] N. Pedro, "Infrasestruturas, Redes, Tecnologias e ambientes oline: em que salas de aula?". Aprendizagem, TIC e Redes Digitais, pp. 100-111. Lisboa: CNE - Conselho Nacional de Educação, 2017.

[4] F. Costa (Coord.). Competências TIC. Estudo de Implementação, (Vol.II). Lisboa: GEPE/ME, 2009. Retrieved from http://www.gepe.min-edu.pt/np4/364.html

[5] J. P. Ponte et al. Relatório de avaliação 2005/2006 do Projecto Competências Básicas em TIC nas EB1. Equipa de Recursos e Tecnologias Educativas/ Plano Tecnológico da Educação. (2007). Retrieved from http://www.crie.minedu.pt/files/@crie/1193391766_Relatorio_Executivo_CBTIC_26_10

[6] A. Ramos \& A. Osório, "A formação de animadores no processo de desenvolvimento de competências básicas em Tecnologias de Informação e Comunicação no âmbito do projecto CBTIC@EB1 no distrito de Braga”. IE Comunicaciones, Revista Iberoamericana de Informática Educativa. no 7/8, pp. 31-42, 2008. Retrieved from http://161.67.140.29/iecom/index.php/IECom/article/viewFile/161/155

[7] F. Costa (Coord.). Competências TIC. Estudo de Implementação. Lisboa: GEPE/ME, 2008. Retrieved from http://www.gepe.min-edu.pt/np4/364

[8] Portaria n. ${ }^{\circ} 731 / 2009$, de 7 de Julho. Diário da República n. ${ }^{\circ}$ 129/2009, Série I de 2009-07-07. System of Training and Certification in ICT Skills for Functioning Teachers in Preschool and Basic and Secondary Education Establishments. 
[9] Resolução do Conselho de Ministros n. ${ }^{\circ}$ 137/2007, de 18 de Setembro. Approves the Technological Plan of Education.

[10] Gabinete de Estatística e Planeamento da Educação (GEPE), "Modernização tecnológica do ensino em Portugal. Estudo de Diagnóstic". Lisboa: Ministério da Educação, 2008. Retrieved from

http://www.dgeec.mec.pt/np4/100/\%7B \$clientServletPath\%7D/?newsId=160\&fileName=mt_ensi no_portugal.pdf

[11] Portaria n. $.^{\circ} 121 / 2016$, Diário da República n. ${ }^{\circ} 79 / 2016$, Série II de 2016-04-22. To proceed to the distribution of charges relating to the contract for the purchase of connection services of the electronic system.

[12] S. Oliveira, Computadores das escolas em risco de parar. Educare.pt, 2012. Retrieved from https://www.educare.pt/noticias/noticia/ver/?id=14009\&langid=1 